\title{
Information literacy on the political agenda: An analysis of Estonian national strategic documents
}

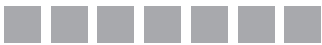

Kertti Merimaa

ORCID: 0000-0002-6888-4661

MINISTRY OF SOCIAL AFFAIRS, ESTONIA

Krista Lepik

ORCID: 0000-0002-6576-4429

UNIVERSITY OF TARTU

https://doi.org/10.19195/1899-5101.13.2(26).3

\begin{abstract}
There is a controversy: while information literacy (IL) has been recognized to have a central role in operating efficiently in the information society, previous studies have noted that in the European political agenda, the actual wording of IL is rarely used. This study pays a close visit to 15 Estonian information policy-related national strategic documents from 1998 to 2014 to understand the emerging role of IL in these documents. Qualitative text analysis and critical discourse analysis are employed to analyse both explicit representations and implicit conceptualizations of IL, linked to social determinants, ideologies, and effects from the dominating discourse. Considering the different "faces" of IL (Bruce, 1997), one can see that while the dominant approach to IL is technologically oriented, few other concepts of IL can be detected. Discursively, the information society is defined through economic and technological fields, on the wave of technological determinism and neoliberalism, with some social equality.
\end{abstract}

KEYWORDS: information literacy, information society, policy, critical discourse analysis, qualitative text analysis, Estonia

\section{INTRODUCTION}

Estonia is claimed to be a pioneering information society (Runnel et al., 2009) that widely holds a perception of a leading e-state that has successfully merged information and communication technologies (ICTs) with its education system, having acquired international recognition for its success in the areas of e-governance and 
services. The development of an information society has been a strategic priority of the Estonian government for the last 20 years, as can be deduced from the number of topical strategic documents. However, conducting a cursory inspection of policies leading the governmental development shows that the notion of information literacy (IL) seems to fit vaguely into the scope of the information society in Estonia, even though IL has been recognized to have a central role in operating an information society efficiently (Horton, 2007; Eisenberg, 2008). However, the need for governmental political prioritization and support for IL to be developed to its full potential has been expressed by academics (Virkus, 2013; Weiner, 2014).

Expressions of IL in policies have been researched before: a broad overview of IL concepts (including in policies) in Europe has been given by Virkus (2003, 2013); numerous useful studies have been conducted to clarify several aspects of IL in the political sphere (Basili, 2011; Pilerot \& Lindberg, 2011; Weiner, 2011; Whitworth, 2011). Basili (2011) has analysed IL policies in European countries and has included three policy initiatives from Estonia. Also, Frau-Meigs and colleagues (2017) have, in their cross-country mapping of media and information literacy (MIL) policies, included Estonia, but predominantly from the perspective of media education. Therefore, a more detailed, up-to-date understanding of the actual role of and political support for IL in Estonia is still needed. Thus, the primary purpose of the present study is to develop an understanding of the emerging role of IL in Estonian information policy-related national strategic documents. In this way, the paper aims to contribute to the discussions about uncontested aspects of IL development in policy documents in general.

The study analyses Estonian national strategic documents with the help of qualitative text analysis about how IL is represented in the context of the information society. In order to do so, the paper pays attention to the possible changes of representation in time, involving strategic documents from different periods into the study. As the understanding of what information society means may have an impact on which topics are prioritized in the concept, the paper also assesses the information society discourses represented in the chosen documents, using a critical discourse analysis framework.

\section{THEORETICAL FRAMEWORK}

As defining the IL concept through different perspectives has been an ongoing task since Paul Zurkowski (1974), the attempts to make sense of IL have taken ever more elaborate forms, such as various reviews, models, and taxonomies (Bawden, 2001; Lupton \& Bruce, 2010; Stordy, 2015). Despite discord between various definitions, there is some agreement that IL can be seen at different levels as a generic instrumental skillset learned individually or as situated in a social context (Lupton \& Bruce, 2010; Street, 2003), that IL embeds or is strongly related to an ICT component (Bruce, 1997; Bawden, 2001; Stordy, 2015), and that it has collaborative or 
participatory properties, enabling individuals and groups to challenge the status quo (Lankshear \& Knobel, 2007; Lupton \& Bruce, 2010).

Regarding the different levels of approaches to IL, the instrumental view, sometimes also referred to as the "generic model" (Lupton \& Bruce, 2010) or the "autonomous model" (Street, 2003), is probably the most well known. Within this view, authors usually propose a definite list of competencies that make a person information literate (e.g., Burchinal, 1976; Doyle, 1994; SCONUL Working Group on Information Literacy, 2011; Association of College and Research Libraries, 2016). With this, the literacy skillset is seen as an independent asset that instrumentally has a one-way effect on people's social practices and cognitive functioning (Street, 2003). The generic or autonomous model is reflected in many definitions and models of IL promoted by the academic library community, including SCONUL's seven pillars of information literacy model (SCONUL Working Group on Information Literacy, 2011), which is often used as a theoretical framework of studies (e.g., Cope \& Sanabria, 2014; Sandercock, 2016), and versions of the ACRL Framework for Information Literacy for Higher education (Association of College and Research Libraries, 2000, 2016), also used for numerous studies (Gross \& Latham, 2012; Seiler et al., 2012; Adams et al., 2016). Alternatively, IL can be regarded "as a range of contextualized information practices" (Lupton \& Bruce, 2010, p. 12). The "situated model" (Lupton \& Bruce, 2010) or "ideological model" (Street, 2003) reflects the understanding that literacies are part of a social construct. As a social practice itself, IL is affected by persons' environment and their ideological conception of the world, while the conception of IL can be derived from personal experience, referring to "different patterns of meaning" (Bruce, 1997, p. 151).

In the multiplicity of concepts related to IL, the extent of the ICT component within or in relation to IL has been a topic of debate. The concept of IL has embraced skillful usage of technologies since its first mention by Zurkowski (1974), who includes in his comprehensive list of "information tools" (that the informationliterate person should be able to use) also "computer data bases" (sic!) (Zurkowski, 1974, p. 4). In a similar vein, despite their differences (Stordy, 2015), both the ACRL and SCONUL models position IL with a clear focus on information-related skills into an environment rich in various ICTs. While there are technology-oriented, skill-based "neighboring" literacies, such as computer literacy or IT literacy (Bawden, 2001), the notion of digital literacy has evolved from "an ability to read and understand hypertextual and multimedia texts" (Bawden, 2001, p. 246) to "the confident and critical use of ICT" (European Commission, 2007, as cited in Stordy, 2015, p. 464), in various contexts. Eventually, there is UNESCO's concept of MIL, which involves not only information-oriented literacies such as IL or media literacy but also technology-oriented literacies such as computer literacy or digital literacy (UNESCO, 2013, p. 13); as an umbrella term, it aims to capture the same areas as the SCONUL, but in a broader context than higher education. One way or the other, IL contains certain ICT-related components, but it can be a matter of context whether 
the IT skills as presuppositions to IL have already been obtained by one or another target group, or whether it is still seen as a future goal.

Third, the "transformative model" of IL includes both the elements from the aforementioned "generic model" and the "situated model", where "[IL] is seen as a range of information practices used to transform oneself and society" (Lupton \& Bruce, 2010, p. 13). In this model, one questions information and knowledge, trying to understand "inherent assumptions in the information" (Lupton \& Bruce, 2010, p. 13). Albeit that critical thinking has been considered an essential component of IL in earlier definitions (Association of College and Research Libraries, 2000), the coming of Web 2.0 especially, enabling users to create and publish content "in a participatory and collaborative fashion" (Kaplan \& Haenlein, 2010, p. 61), also changes the ways of defining literacies as more "participatory" and "collaborative" (Lankshear \& Knobel, 2007; SCONUL Working Group on Information Literacy, 2011).

The three aspects (context dependency, the ICT component, and, to some extent, the transformative nature of IL) are also embedded in Christine Bruce's view of IL in "Seven Faces of Information Literacy", which aims to capture the varying experiences of IL rather than the strict definition of the concept (Bruce, 1997). Bruce (1997) distinguishes seven types of conceptions that reflect how people might experience IL: (1) The Information Technology (IT) experience, where the focus is on information technology that helps users stay informed or communicate; (2) the Information Sources experience, focusing on the personal skills of finding and accessing information from various information sources; (3) the Information Process experience, linked to filling in information gaps for problem solving or decision making; (4) the Information Control experience, focusing on managing the relevant information; (5) the Knowledge Construction experience, with a focus on usage and, moreover, critical analysis of information to develop a personal perspective with knowledge gained; (6) the Knowledge Extension experience, focusing on the intuitive usage of information to develop new knowledge or approaches to tasks or novel solutions - hence "transforming" the information or producing new knowledge; and (7) the Wisdom experience, where the information is ethically used for the benefit of oneself or others (counseling, explaining, etc.) - hence "transforming" the people.

Each differentiated experience presents different sides of IL, whereas the conceptions themselves are in a loosely hierarchical relationship, where the first conception could be a conditional prerequisite for the next conception. Though in a relationship, Bruce claims that IL is not at all a linear phenomenon, where IL could be seen to have a central role. Bruce's "seven faces of information literacy" model is chosen to be the basis of the present study, as, deriving from a relational and experiential approach to IL, it enables one to look for a more extensive array of indications of IL in different contexts and through the different ways in which IL is experienced. Moreover, her model helps in the present study to detect IL in the analysed texts without the actual phrase being used and to understand which aspects of IL matter the most in the context of the information society in Estonia. 
When interpreting IL in texts, the conceptualization of a term may differ significantly between texts with different purposes. Pilerot and Lindberg (2011) point out that, depending on the context in which IL is interpreted, the concept is perceived to have a different focus, and how the concept is understood and approached also differ: for example, is the achievement of IL an objective or a separate object to explore? Meanwhile, in depicting the peculiarities of information competence in political texts, one can see the concept as a political goal and a means to achieve other political goals. Tuominen and colleagues (2005, p. 330) argue that most IL texts are, by their nature, normative explanations of what information skills are needed in today's society. Pilerot and Lindberg (2011) stress that, contrary to the scientific context, IL has been described and understood in the political context as a normative and relatively clear set of generic skills. In their view, IL in policy texts is conceived as a competency focused on critical thinking that is certainly individual and, at least to some extent, measurable. IL itself is, in this case, associated with digital and textual sources, which may, however, occur in different practices.

While the importance of promoting IL at the national level has been stated in international declarations, such as the Prague Declaration (UNESCO, 2003), the concept of IL has rarely been used explicitly in national political documents. Whitworth (2011) points out that IL is rarely mentioned in texts of a higher political level, as the term is usually included as part of the information society agenda, which, by its very nature, focuses more on developing ICT skills and infrastructure. Arguably, Finland has been the only country whose policy texts at the national level have directly reflected IL, while in other countries, IL was represented only in sub-sectorial documents, and different countries have interpreted IL from different perspectives (Whitworth, 2011). The lack of IL in the European political agenda is also noted by Basili (2011) and Virkus (2013), who has pointed out that even though IL is conceptually represented in European policies, the actual wording of IL is rarely used.

As the study focuses on the policy implications of IL in the context of the information society, it is also essential to open the meaning of the latter concept. "Information society" is often used to describe the most recent stage of social history, where different kinds of information have started to have an increasingly important role in different areas of society, such as economic, political, social, and cultural. Bornman (2015) describes the information society as associated with the proliferation of information and technology that would enable new, better, and faster ways to create, store, and distribute information. In this rapid exchange of information, IL has been recognized as having a central role in efficiently operating in the information society (Eisenberg, 2008), as it equips people not only with technical skills but also with a broad, integrated, and critical view on the world of knowledge and information (Shapiro \& Hughes, 1996). From this point of view, both IL and information society are undoubtedly interconnected concepts, so when examining the two concepts together, the information society concept likely impacts the 
conception of IL. From that perception, the present study takes a glance at discursive structures prevalent in the concept of the information society in Estonia, with the expectation to conceive how the understanding of the information society might influence the representations of IL in Estonia.

Considering the need to provide an up-to-date understanding of the actual role of and political support for IL in Estonia, the paper seeks to address the following questions:

RQ1: Through which of Bruce's (1997) conceptions is the concept of IL represented in Estonian national strategic documents directing the information society?

RQ2: Has the representation of IL in political texts changed over time, and if it has, how?

RQ3: Which discursive structures can be detected in the representation of the concept of the information society in Estonian national strategic documents directing the information society, and how do the findings elucidate the findings of RQ1?

\section{METHODOLOGY}

The methodological approach taken in this study is based on qualitative text analysis and critical discourse analysis. As the objective of the present study is to understand the representations of IL in the context of the information society, the study focuses on Estonian national strategic documents that are linked with the information society and could in any way refer to IL. In order to perceive possible development or changes in representations over time, documents from two decades have been involved: first, representing the period of 1998-2009, and second, 2010-2019 (see Table 1). Within these two periods, it is possible to see that national strategic documents were issued in waves, the first involving the period between 2004 and 2007 and the second with the time span of 2013-2014. After 2014, no national strategic document that would fit into the sample has been issued, hence the gap between the issuing years of the last documents and the time of publishing this article.

It has been a common practice for the strategic documents in Estonia to refer extensively to one another, suggesting that the authors of the strategies see domains covered by the strategies as interconnected. The interconnectivity of texts means that all the other strategic documents that are seen as related are listed down in documents, while the ones not seen as related are not cited. While retrieving documents for the study, the authors followed similar logic: first, by detecting all strategies that were directly creating a strategy for the concept of information society (for example, "The Estonian Information Society Development Plan 2013"), and second, by including the documents listed in the aforementioned strategies that are seen (by the creators of the documents) as indirectly related to information 
society (for example, “The Estonian Lifelong Learning Strategy 2005-2008”, which is referred to in "The Estonian Information Society Development Plan 2013"). This selection basis made it possible to take into account the thought patterns of the documents' authors and to perceive a more authentic understanding of how the public sector conceptualizes an information society. This choice also minimized the risk of detecting the representations of IL that actually are not connected to the concept of information society discourse in Estonia. However, two documents that were referred to in the source documents were not included in the study, as full texts of these documents were inaccessible at the time of conducting the study. These documents were "The Studying Tiger" ("Õppiv Tiiger") and "Tiger's University 2005-2008” (“Tiigriülikool 2005-2008”), from the period of 1998-2009, focusing on the implementation of ICT in the education system within "The Tiger Leap Program" (Runnel et al., 2009). Presumably, including those texts in the study would not have had a substantial impact on the results, as the more general document of the same domain ("General Education System Development Plan 2007-2013") likely presented the same conceptions of IL.

For the qualitative text analysis to answer RQ1, all documents mentioned in Table 1 were included in the study. For the discourse analysis, only directly related documents were included, as this helped to keep the focus on detecting discursive structures prevalent in the concept of the information society.

For context, it is also important to mention that after the collapse of the Soviet Union, strong inclinations "to return to the Western world" (Rosengren et al., 1997) have been dominating not only the political but also the cultural landscape. Eventually, joining both the European Union and NATO in 2004 has greatly influenced the policymaking scene together with ruling discourses in Estonia, as can be deduced from the European Union enlargement policy (European Union, 2016). By default, strategic documents in Estonia are quite likely to be influenced by the ruling paradigms in the offices issuing them, which can also have an impact on what and how is constituted in the strategies. For this reason, Table 1 shows which offices led the composition of the documents.

In order to examine how the IL concept is represented in Estonian national strategic documents and whether it has changed over time, qualitative content analysis was used. The strength of this method is the ability to consider the latent content of the text, allowing the researcher the opportunity to highlight the possible purpose of the text and, for example, the author's hints.

All the segments that contained either directly or in substance a reference to IL or a concept related to the latter were coded using MAXQDA software. All segments found were categorized according to the type of Bruce's (1997) experiences of IL, as outlined in the theoretical section. Also, the analysis took into account the specialties of expressing IL in political texts, as mentioned in the theoretical background. In order to detect possible differences in the depictions of IL throughout documents from each of the two time periods, the period to which each segment belonged was marked. 
Table 1. The national strategic documents included in the analysis

\begin{tabular}{|c|c|c|c|c|}
\hline $\begin{array}{l}\text { Period } \\
\text { of issuing }\end{array}$ & $\begin{array}{l}\text { Document's } \\
\text { relation to } \\
\text { information } \\
\text { society }\end{array}$ & $\begin{array}{l}\text { Title of the national strategic } \\
\text { document in English* and in } \\
\text { Estonian }\end{array}$ & $\begin{array}{l}\text { Year of } \\
\text { issue }\end{array}$ & Issuing body \\
\hline \multirow{7}{*}{$\begin{array}{l}\text { Earlier } \\
\text { period } \\
(1998-2009)\end{array}$} & Direct & $\begin{array}{l}\text { Principles of Estonian } \\
\text { Information Policy (Eesti } \\
\text { infopoliitika põhialused I) }\end{array}$ & 1998 & Estonian Parliament \\
\hline & Direct & $\begin{array}{l}\text { Principles of Estonian } \\
\text { Information Policy } \\
\text { 2004-2006 (Eesti infopolii- } \\
\text { tika põhialused aastateks } \\
\text { 2004-2006) }\end{array}$ & 2004 & $\begin{array}{l}\text { Estonian Govern- } \\
\text { ment }\end{array}$ \\
\hline & Direct & $\begin{array}{l}\text { The Estonian Information } \\
\text { Society Development Plan } \\
2013 \text { (Eesti infoühiskonna } \\
\text { arengukava 2013) }\end{array}$ & 2006 & $\begin{array}{l}\text { Ministry of } \\
\text { Economic Affairs } \\
\text { and Communica- } \\
\text { tions }\end{array}$ \\
\hline & Indirect & $\begin{array}{l}\text { The Estonian Lifelong } \\
\text { Learning Strategy } \\
\text { 2005-2008 (Elukestva oppe } \\
\text { strateegia 2005-2008) }\end{array}$ & 2005 & $\begin{array}{l}\text { Ministry of } \\
\text { Education and } \\
\text { Research }\end{array}$ \\
\hline & Indirect & $\begin{array}{l}\text { Estonian entrepreneurship } \\
\text { policy 2007-2013 (Eesti } \\
\text { ettevõtluspoliitika } \\
\text { 2007-2013) }\end{array}$ & 2006 & $\begin{array}{l}\text { Ministry of } \\
\text { Economic Affairs } \\
\text { and Communica- } \\
\text { tions }\end{array}$ \\
\hline & Indirect & $\begin{array}{l}\text { Knowledge Based Estonia } \\
\text { 2007-2013 (Tead- } \\
\text { mistepõhine Eesti } \\
\text { 2007-2013) }\end{array}$ & 2006 & $\begin{array}{l}\text { Ministry of } \\
\text { Education and } \\
\text { Research }\end{array}$ \\
\hline & Indirect & $\begin{array}{l}\text { General Education System } \\
\text { Development Plan } \\
\text { 2007-2013 (Üldhari- } \\
\text { dussüsteemi arengukava } \\
\text { 2007-2013) }\end{array}$ & 2007 & $\begin{array}{l}\text { Ministry of } \\
\text { Education and } \\
\text { Research }\end{array}$ \\
\hline & Direct & $\begin{array}{l}\text { Estonian Digital Agenda } \\
2020 \\
\text { (Eesti infoühiskonna } \\
\text { arengukava 2020) }\end{array}$ & 2013 & $\begin{array}{l}\text { Ministry of } \\
\text { Economic Affairs } \\
\text { and Communica- } \\
\text { tions }\end{array}$ \\
\hline & Direct & $\begin{array}{l}\text { Estonian Digital Agenda } \\
2020 \\
\text { (Eesti infoühiskonna } \\
\text { arengukava 2020) }\end{array}$ & 2013 & $\begin{array}{l}\text { Ministry of } \\
\text { Economic Affairs } \\
\text { and Communica- } \\
\text { tions }\end{array}$ \\
\hline
\end{tabular}


Information literacy on the political agenda

\begin{tabular}{|c|c|c|c|c|}
\hline \multirow{7}{*}{$\begin{array}{l}\text { Later period } \\
(2010-2019)\end{array}$} & Indirect & $\begin{array}{l}\text { Development Plan of the } \\
\text { Estonian Language } \\
\text { 2011-2017 (Eesti keele } \\
\text { arengukava 2011-2017) }\end{array}$ & 2010 & $\begin{array}{l}\text { Ministry of } \\
\text { Education and } \\
\text { Research }\end{array}$ \\
\hline & Indirect & $\begin{array}{l}\text { Estonian Cyber Security } \\
\text { Strategy 2014-2017 } \\
\text { (Küberjulgeoleku strateegia } \\
\text { 2014-2017) }\end{array}$ & 2013 & $\begin{array}{l}\text { Ministry of the } \\
\text { Interior }\end{array}$ \\
\hline & Indirect & $\begin{array}{l}\text { The Estonian Lifelong } \\
\text { Learning Strategy } \\
\text { 2014-2020 (Eesti elukestva } \\
\text { õppe strateegia 2014-2020) }\end{array}$ & 2013 & $\begin{array}{l}\text { Ministry of } \\
\text { Education and } \\
\text { Research }\end{array}$ \\
\hline & Indirect & $\begin{array}{l}\text { Estonian Entrepreneurship } \\
\text { Growth Strategy 2014- } \\
2020 \text { (Eesti ettevõtluse } \\
\text { kasvustrateegia 2014-2020) }\end{array}$ & 2013 & $\begin{array}{l}\text { Ministry of } \\
\text { Economic Affairs } \\
\text { and Communica- } \\
\text { tions }\end{array}$ \\
\hline & Indirect & $\begin{array}{l}\text { Estonian Regional } \\
\text { Development Strategy } \\
\text { 2014-2020 (Regionaalar- } \\
\text { engu strateegia 2014-2020) }\end{array}$ & 2013 & $\begin{array}{l}\text { Ministry of the } \\
\text { Interior }\end{array}$ \\
\hline & Indirect & $\begin{array}{l}\text { Estonian Research and } \\
\text { Development and } \\
\text { Innovation Strategy } \\
2014-2020 \text { "Knowledge- } \\
\text { Based Estonia" (Eesti } \\
\text { teadus- ja arendustegevuse } \\
\text { ning innovatsiooni [TAI] } \\
\text { strateegia 2014-2020 } \\
\text { „Teadmistepõhine Eesti“) }\end{array}$ & 2014 & $\begin{array}{l}\text { Ministry of } \\
\text { Education and } \\
\text { Research }\end{array}$ \\
\hline & Indirect & $\begin{array}{l}\text { National Defence Strategy } \\
\text { 2015-2020 (Siseturvalisuse } \\
\text { arengukava 2015-2020) }\end{array}$ & 2014 & $\begin{array}{l}\text { Ministry of the } \\
\text { Interior }\end{array}$ \\
\hline
\end{tabular}

* Titles were translated into English by the authors.

Source: Authors.

The information society discourse analysis was conducted on the basis of the critical discourse analysis method developed by Norman Fairclough (1989). In discourse analysis, language is studied in a social context with a critical and interpretive attitude to create systems of social meaning (Tonkiss, 1998). Texts that belong to the same discourse often use similar indicative vocabulary, grammatical, or stylistic expressions to manifest the expression as correct or as inevitable fact (Bryman, 2008). Tonkiss points out that language is both an active and a functional tool to 
(re)create social relationships, identities, and ideas (Tonkiss, 1998). Therefore, it can be argued that discourse analysis provides a convenient way of analysing how language and text are used as purposeful instruments and give an understanding, in the context of the current study, of which ideologies and power relations influence the representations of IL in an information society discourse, and vice versa: how the discourse itself has a constructive effect on social relations, beliefs, and identities.

The critical discourse analysis of Fairclough (1989, p. 26) used in the current study proposes interrelated dimensions of discourse:

1) a description of the text focusing on the formal characteristics of the text;

2 ) interpretation of discursive practices used in the text that focus on the text production process and its interpretation from the recipient's perspective;

3) explanation of the use of language as a social practice that focuses on the social context of the text, as the prevailing socio-cultural practices affect both the creation and the interpretation of different texts.

As the goal of the study was to find discursive structures prevalent in the concept of the information society, for the critical discourse analysis, only the Estonian national strategic documents directly driving its information society were included (see Table 1). This decision was made with the premise that the analysis of discourses considering the information society will be saturated even without including other strategic documents. The included documents were then analysed by using MAXQDA qualitative text analysis software. From all the documents, excerpts concerning the concept of information society were first separated under one code and then, as a second step, analysed and categorized by the different discourse that the excerpt represented.

During the coding process, analytical questions about experiential, relational, and expressive values were used to analyse vocabulary, grammar, and text structures (Fairclough, 1989, pp. 110-111). Then, the segments were analysed to distinguish the peculiarities of text production and intertextuality to understand how the text could be interpreted and why the text was created as it was. As the last step, it was examined how the coded segments of discursive structures describing the information society were affecting and were influenced by the social realities and the ruling ideologies surrounding them. This enabled the researchers to "portray a discourse as part of a social process, as a social practice, showing how it is determined by social structures, and what reproductive effects discourses can cumulatively have on those structures, sustaining them or changing them" (Fairclough, 1989, p. 163). Under particular scrutiny were the questions on social determinants (regarding the power relations at the situational, institutional, and societal levels to shape particular discourses), ideologies, and effects (related to the position, normativity, and struggle of the discourse) (Fairclough, 1989, p. 166). 


\section{RESULTS}

The following chapter presents the results of the analysis in the order of the research questions. First, the chapter discusses which of the "seven faces of information literacy" (Bruce, 1997) correspond to the conceptions of IL represented in Estonian national strategic documents directing the information society. Second, the discussion focuses on the changes of the representation of IL in political texts over two decades. Third, the chapter introduces the discursive structures detected in the representation of the concept of the information society and discusses how these findings may elucidate the findings with regard to representation of IL in the documents under scrutiny.

\section{Representations of information literacy}

Results of the qualitative text analysis implied that the term IL was not explicitly used in the documents under scrutiny. However, the substance of IL was still partly covered. From the "seven faces" of IL, the most present was the first one - the IT experience - while other "faces" from Bruce's model were scarcely present. Of various concepts of IL, the Information Control and Information Process experiences were detectable in the context of digitizing governmental bureaucracy (having greater control over the governmental information). In relation to the concept of IL, the "learning to learn" skills were represented as a part of an educational strategy or vaguely expressed through the application of digital competencies for better information processing and control purposes, but these could also manifest the Knowledge Construction experience of IL. The following discussion will examine these cases a bit further.

Most of the studied documents explicitly describe digital literacies and other basic skills related to ICT, implying that the Information Technology experience is a prevailing representation of IL in the studied texts. It is worth mentioning that the expressions of the concept were aligned with Pilerot and Lindberg (2011), as these were mostly expressed as normative, measurable competencies fulfilling a political agenda - supporting the country's economic growth, being a more active member of the society, and reaching towards an equal society. The competencies mentioned above were presented in the studied texts as critical and necessary to operate successfully in the information society, thus the call for an urgent need to broaden the people's digital skills. For example, in the Principles of Estonian Information Policy 2004-2006, digital literacy as a term is described as a competency necessary to develop within the Estonian population; however, the content of the competency is described as skills related to using a personal computer and Internet connection.

The Information Sources experience and the Information Process experience can be detected in the Estonian Lifelong Learning Strategy 2020, where digital competency is defined as "the readiness to use digital technology to cope with the 
rapidly changing information society at work, in studies, in acting as a citizen, as well as in communicating with one's community" (p. 24). However, when looking into what is meant by "digitally competent" in the studied texts, it can be seen that the documents belonging to an earlier period lean on the IT experience side, and the documents belonging to the latter period have a slightly different approach. In the Estonian Information Society Development Plan 2013, the metric is defined as whether people use the Internet for communication and if they are motivated to participate in society through digital channels (p. 2). In comparison, in the Estonian Digital Agenda 2020, it is claimed that using the Internet for communication, entertainment, and information searches alone is not enough, and a strategic goal needs to be set that the Internet is used more to enhance one's "competitiveness and well-being (e.g., through smarter consumption or internet-based learning opportunities)" (p. 9).

A vague implication for IL through the Information Control experience can be seen in the Digital Agenda 2020, where the term "holistic information governance" is used, linked with a goal of managing information flows better in the public sector (p. 31).

Three other experiences, the Knowledge Construction, Knowledge Extension, and Wisdom experiences of the IL, were detected vaguely in the texts. There were traces of these three in the most current Estonian Digital Agenda, where the differentiation of ICT skills and ICT competencies implied that there are other sides (aside from digital literacy) needed to operate in the information society. ICT skills are defined as skills needed to be able to use the Internet in general, which has a goal of leading towards a more equal society and helping people to participate in society more actively. ICT competencies are treated as a more advanced set of skills: interdisciplinarity, data mining and data analysis, cybersecurity, and so forth, that would enable greater productivity in areas that do not create sufficient added value, increase the competitiveness of professionals in various domains, and achieve economic growth (Estonian Digital Agenda 2020, 2013).

Even though not explicitly expressed, all of the experiences of IL can be detected as a goal in the Estonian Lifelong Learning Strategy 2005-2007, where IL is expressed as functional literacy (p. 21). Experiences of IL can also be noticed in the Estonian Lifelong Learning Strategy 2020, where the necessity of incorporating new knowledge with existing knowledge in the learning process, integrating studies with different subjects and fields, and learning/teaching not only factual knowledge but also how to learn and solve problems, including the team approach to problem solving, are seen as part of the learner's key competencies (p. 7) (also represented in the documents as a general "learning to learn" competency). This indicates that IL might be mostly seen as a concept that is stressed in the education domain and is not necessarily articulated with the connection to the information society. All of the representations of IL in the studied texts fit well into the transformative model approach, as they suggest that a person, while gaining the ICT-related and "learning 
to learn" competencies, will be empowered through the acquired understanding, and thus these competencies are not seen merely as instrumental skills or information practices.

The representations of IL in the two studied periods did not differ significantly, as the concept was never explicitly incorporated into the documents. However, the result of the analysis suggests that, aside from the Information Technology experience, representations of other experiences of IL shifted into the background or within to the ICT-related competencies.

\section{Discursive structures prevalent in the concept of information society}

The following sub-chapter introduces discursive structures prevalent in defining the concept of the information society in the strategies that were directly connected to the concept of the information society (see Table 1). The researchers find discursive structures particularly beneficial to cast some light on why the concept of IL is mostly represented through the prism of ICT and why not all of the "faces" of IL were detectable in the studied texts. The way the concept of the information society is represented, and through that, the way the domain (of the information society) is framed in the studied texts, also has an impact on which sides of IL are emphasized (and which are not) in the same texts.

The term "information society" ("infoühiskond" in Estonian) is considered a neologism in the Estonian language, as the term became used only at the very end of the 20th century. In the studied texts, the concept was mostly presented in two main ways: as a destination that the country should strive towards and as the present societal order. When information society is represented as a desirable objective, it is seen as the provider of the means for Estonia to obtain a meaningful global position and become a part of Europe, sharing both ideological and economic goals, such as the rise of equality and materialistic means. Information society as a current reality was always presented together with an educational need - as information society is already present, people need digital literacy to be able to operate in society successfully. This is presented as a crucial need, as Estonia itself is described through the discourse as a small country that is lacking resources (Principles of Estonian Information Policy 2004-2006, p. 9). These two ways to present the information society were co-existing in the first of the national strategic documents analysed (Principles of Estonian Information Policy), while in the following documents, the information society was presented as a current reality.

In the analysed texts, the notion of information society appears to be intertwined with economic and technological fields, where the success of the information society is linked with economic success, which in turn is dependent on the application of technological solutions. People's operational abilities in the information society are, hence, tightly tied together with digital competencies. Economic success is presented as critically dependent on this knowledge (more explicitly, ICT competencies). This can also be seen in the terms used in the texts, such as "knowledge-based 
economy". Competencies that are part of IL, such as the correct use of information, are seen as tools for economic growth - increasing both personal well-being and the country's wealth.

It can be argued that this portrayal is likely to be adopted from the European Union's (EU) presentation of the information society, portraying the concept of the information society through the technology and knowledge-based economy (Goodwin \& Spittle, 2002; Singh \& Gurumurthy, 2006). The knowledge-based economy as a discourse itself is linked with employment and social cohesion, which can most explicitly be seen in the Lisbon Strategy (Aava, 2009). As technological advancement is portrayed as one of the leading influencers of the economy in the texts studied, it can be argued that the information society is seen to be led by technological determinism. Studied national strategic texts give a message that whoever has control over technology (mainly by being ICT competent) is economically in a stronger position. ICT competencies are seen as playing a vital role in the employment market - having the competencies significantly improves one's career outlook, whereas not having the competencies will cause a less positive outlook for life. The national strategic documents under scrutiny were issued by the Ministry of Economic Affairs and Communication; as the domain of this ministry involves economic growth and technological developments, the aforementioned discursive elements match well with the domain.

Another discursive structure prevalent in the strategic documents is the notion of neoliberalism, as the texts suggested that the responsibility for one's well-being is left to the person herself or, alternatively, to the private sector, which is expected to make use of ICT possibilities in the creation of material profit. For example, the Estonian Digital Agenda 2020 declares:

Skillful usage of ICT provides the remarkable potential to create job positions yielding higher added value and raising the quality of life for people. An important precondition to use e-solutions is the awareness about opportunities and threats related to the information society, including skills to protect oneself from the latter. (p. 18)

Education is seen as a primary tool for the state to enable people to increase their quality of life. At the same time, social equality is treated as an essential merit in the information society. Throughout the studied texts, the goal of reducing the digital divide is present. The Digital Agenda 2020 declares, "[I]nformation society will be created for all residents of Estonia, while particular attention will be paid to the integration of social groups with special needs, to regional development and the strengthening of local initiative" (p. 17), implying that solidarity has an eminent role in the discourse of the information society. These last goals seem to be more social-democratic, which places the main emphasis on the four values: freedom, equality, justice, and solidarity, as Kastning (2013) argues.

These discursive structures together form a relatively coherent multifaceted discourse of information society in a small and flexible country where overall economic ambitions are achieved by tech-savvy and self-sustaining citizens, who are 
assisted by the state in case they should experience issues caused by the digital divide. As the analysis involved national strategic documents, all of which are future oriented, this discourse of information society reflects a dream to come true, while little emphasis has been put on actual suggestions about how to achieve the desired goal.

\section{CONCLUSIONS AND DISCUSSION}

The results of the study showed that IL was mainly represented through digital and ICT skills and not explicitly present in any of the studied documents. However, in one way or another, different "faces" of IL could be detected. This result aligned with previous studies (Whitworth, 2011), according to which, in the context of the information society, where digitization is one of the main topics, the main focus of IL is actually on digital literacy. The representation of IL in the studied documents did not change over time, being steadily represented mostly through digital literacies; however, the understanding of digital literacy itself changed over the two periods, binding more IL-related concepts into itself during the recent period than in the earlier.

The findings of the qualitative text analysis are solidly backed by the results of the discourse analysis. By exploring the discursive structures defining information society, one can see that the conceptualization of information society itself might well have a significant impact on how the concept of IL is represented in the context of the information society. When the understanding of information society is strongly led by thoughts of technology and economics, then it becomes more evident why IL is present mostly through the experience of information technology. Even though the other experiences of IL were presented vaguely behind the more complex ICT skills or could be seen in need of more efficient governance, it can still be argued that IL is not viewed as an integral part of these concepts but rather as a presumption that does not need to be separately brought out or developed.

The information society-related discursive patterns go hand in hand with the discursive ones that define the EU's practice of representing the term information society, suggesting that Estonia's political strategy follows the strategies of the EU. Also, it could be seen from the discourses that Estonian national strategic documents follow the characteristics of the discourses expressed in Western society, thereby (re)establishing power relations in place. As the information society itself was mainly defined through technology, it can be explained why the IL concept was mainly presented through digital competencies. This is understandable, considering Estonia's recent history and the position at the international stage during the formation of the documents under scrutiny. It has been important for Estonia to follow the same rhetoric as its closest allies, and for the concepts of IL and information society, the approach seems no different. 
At the national level, one can also see that approaches to the information society, as well as, indirectly, to the IL, are much influenced by the domain in which the issuing institution (of the strategic document) is operating. For example, in the case in which the domain of the ministry as the issuing institution involves economic and technological developments, the representations of information society reflect the same domain. Therefore, even in the case that the development of further agendas for the information society is an open process, with the possibility for different stakeholders to suggest varying ideas and, hence, to increase the multiplicity of discourses in information society policymaking, one still needs to consider whether all relevant stakeholders in the context of information society have been informed about and involved in the development process of the new agenda. When one thinks about the information society discourse in Estonia, it is possible to argue that a technologically inclined view of economic success has its strengths; yet, borrowing from the different conceptions or experiences of IL, it can be but the tip of the iceberg. Stakeholders from different fields, such as culture, science, and social welfare, were present in the concept of the information society only from the perspective of economic advancement, indicating that the creators of the strategic documents do not see these fields as explicit parts of the information society. As IL has predominantly been promoted by (academic) library communities (Pilerot \& Lindberg, 2011; Stordy, 2015), the voice of these communities may be too weak to be heard in the economy-inclined approach to the information society. This is also evident from the fact that, in the practice of listing down related strategies, the documents concerning the information society does not list many other domains as related. As such, the authors' observation supports a suggestion made by Basili (2011) to consider agents, stakeholders, or, broadly speaking, the institutional settings of similar strategic documents for similar kinds of comparative analyses on the presence of IL or similar concepts in information policy-making texts.

By exploring the discursive structures defining information society, the present authors consider critical discourse analysis a handy tool, especially when considering the social determinants, ideologies, and effects of discourses (Fairclough, 1989, p. 166). However, the complexity of discourse analysis in ensuring analyst objectivity must be noted. Post-structuralist discourse analysis assumes that the reality created in texts is shaped, to a large extent, by the knowledge, values, and experiences of the individual reading the text. Therefore, it is difficult for analysts to notice all the realities created in the text and to keep from transferring their own experiences into it. Furthermore, discourse analysis requires in-depth knowledge of the social and historical constructs surrounding the text. Background knowledge helps the analyst to find and notice discourse through and surrounding the text and to contextualize it socio-culturally. Therefore, the current study benefited from the experiences of one of the authors, whose background is closely related to public service.

The research can be further developed by including more Estonian strategic documents that are not necessarily directly related to information society or that are more 
detailed and operationally oriented, such as the operational programmes of the Estonian Digital Agenda 2020 (e.g., "Simpler Nation 2020"), in order to find out how both the information society concept and IL are present in a general political documentation landscape. This can be particularly fruitful when one considers the intertextuality of various documents and that the information society-related documents constitute remarkable, yet still only one graspable segment of all governing documents. Also, valuable insights may be obtained by conducting a similar study in different countries to find out if the findings are also evident in other countries - not only in terms of conceptualizations of IL but also in terms of the influences of the national governing bodies and the EU in the policy-making processes. As a result of this, considering the locus of the current study, the authors propose several "constellations": in current political rhetoric, Estonia has been positioned as part of Northern Europe, but it also shares common historical experiences with countries from the Eastern Bloc. Hence, the question for further inquiry may also be related to a comparative approach between different regions. This would highlight additional regional patterns that may be present in both IL and information society discourses in information policy-making texts.

\section{FUNDING AND ACKNOWLEDGEMENT}

This work received support from the European Union ERASMUS+ Strategic Partnership project "Media and Information Literacy \& Innovative Teaching Methods Laboratory" No .2017-1-LV01-KA203-035429. The authors also want to thank the reviewers of this article and the editor of this journal issue for their helpful comments and suggestions.

\section{REFERENCES}

Aava, K. (2009). Haridusalaste tekstide võrdlev diskursuseanalüüs [Comparative discourse analysis of educational texts]. Eesti Rakenduslingvistika Ühingu aastaraamat, 5, 7-18.

Adams, N.E., Gaffney, M.A., \& Lynn, V. (2016). The role of evidence-based practice in collaborations between academic librarians and education faculty. Libraries and the Academy, 16(4), 697-720. https://doi.org/10.1353/pla.2016.0048.

Association of College and Research Libraries (2000). Information literacy competency standards for higher education. http://www.ala.org/ala/mgrps/divs/acrl/standards/informationliteracycompetency.cfm.

Association of College and Research Libraries (2016). Framework for information literacy for higher education. http://www.ala.org/acrl/sites/ala.org.acrl/files/content/issues/infolit/Framework_ILHE.pdf.

Basili, C. (2011). A framework for analyzing and comparing information literacy policies in European countries. Library Trends, 60(2), 395-418. https://doi.org/10.1353/lib.2011.0045.

Bawden, D. (2001). Information and digital literacies: A review of concepts. Journal of Documentation, 57(2), 218-259. https://doi.org/10.1108/EUM0000000007083.

Bornman, E. (2016). Information society and digital divide in South Africa: Results of longitudinal surveys. Information, Communication \& Society, 19(2), 264-278. https://doi.org/10.1080/136911 8X.2015.1065285.

Bruce, C.S. (1997). Seven faces of information literacy. AUSLIB Press. 
Burchinal, L.G. (1976). The communications revolution: America's third century challenge. Texas A \& M University Library.

Cope, J. \& Sanabria, J.E. (2014). Do we speak the same language? A study of faculty perceptions of information literacy. Portal: Libraries and the Academy, 14(4), 475-501.

Doyle, C.S. (1994). Information literacy in an information society: A concept for the information age. ERIC Clearinghouse.

Eisenberg, M. (2008). Information literacy: Essential skills for the information age. DE- SIDOC Journal of Library \& Information Technology, 28(2), 39-47. https://doi.org/10.14429/djlit.28.2.166.

European Union (2016). Conditions for membership. https://ec.europa.eu/neighbourhood-enlargement/policy/conditions-membership_en.

Fairclough, N. (1989). Language and power. Longman.

Frau-Meigs, D., Velez, I., \& Michel, J.F. (2017). Mapping media and information literacy policies: New perspectives for the governance of MIL. In D. Frau-Meigs, I. Velez, \& J.F. Michel (Eds.), Public policies in media and information literacy in Europe (pp. 19-88). Routledge.

Goodwin, I. \& Spittle, S. (2002). The European Union and the information society: Discourse, power and policy. New Media \& Society, 4(2), 225-249. https://doi.org/10.1177/146144480200400206.

Gross, M. \& Latham, D. (2012). What's skill got to do with it? Information literacy skills and selfviews of ability among first year college students. Journal of the American Society for Information Science and Technology, 63(3), 574-583. https://doi.org/10.1002/asi.21681.

Horton, F.W.Jr. (2007). UNESCO: Understanding information literacy: A primer. UNESCO. https:// eduq.info/xmlui/bitstream/handle/11515/17980/157020e.pdf?sequence $=1$.

Kaplan, A.M., \& Haenlein, M. (2010). Users of the world, unite! The challenges and opportunities of Social Media. Business Horizons, 53(1), 59-68. https://doi.org/10.1016/j.bushor.2009.09.003.

Kastning, T. (2013). Basics on social democracy. http://www.fesghana.org/uploads/PDF/Brochure_SocialDemocracy_FINAL.pdf.

Lankshear, C., \& Knobel, M. (2007). Sampling "the new" in new literacies. In M. Knobel \& C. Lankshear (Eds.), A new literacies sampler (pp. 1-24). Peter Lang.

Lupton, M. \& Bruce, C. (Eds). (2010). Windows on information literacy worlds: Generic, situated and transformative perspectives. Centre for Information Studies, Charles Sturt University.

Pilerot, O. \& Lindberg, J. (2011). The concept of information literacy in policy-making texts: An imperialistic project? Library Trends, 60(2), 338-360.

Rosengren, K. E., Lauristin, M., \& Vilhalemm, P. (Eds.). (1997). Return to the Western world: Cultural and political perspectives on the Estonian post-communist transition. Tartu University Press.

Runnel, P., Pruulmann-Vengerfeldt, P., \& Reinsalu, K. (2009). The Estonian tiger leap from postcommunism to the information society: From policy to practice. Journal of Baltic Studies, 40(1), 29-51. https://doi.org/10.1080/01629770902722245.

Sandercock, P. (2016). Instructor perceptions of student information literacy: comparing international IL models to reality. Journal of Information Literacy, 10(1),3-29. https://doi.org/10.11645/10.1.2065

SCONUL Working Group on Information Literacy (2011). The SCONUL seven pillars of information literacy core model for higher education. https://www.sconul.ac.uk/sites/default/files/documents/ coremodel.pdf.

Seiler, V., Miil, K., \& Lepik, K. (2012). How to fit teaching of information literacy in with students' needs: An on-line credit course model from the University of Tartu Library. Liber, 22(1), 42-63. https://doi.org/10.18352/lq.8040.

Shapiro, J.J., \& Hughes, S. K. (1996). Information literacy as a liberal art: Enlightenment proposals for a new curriculum. Educom Review, 31(2).

Singh, P.J., \& Gurumurthy, A. (2006). Framing a global information society discourse. Economic and Political Weekly, 41(10), 876-878.

Stordy, P. (2015). Taxonomy of literacies. Journal of Documentation, 71(3), 456-476. https://doi. org/10.1108/JD-10-2013-0128.

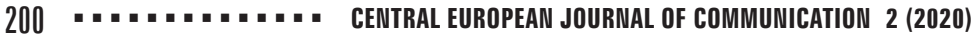

Central European Journal of Communication Volume 13, No 2 (26), Special Issue 2020

(C) for this edition by CNS 
Street, B. (2003). What's "new" in new literacy studies? Critical approaches to literacy in theory and practice. Current Issues in Comparative Education, 5(2), 77-91.

Talja, S., Tuominen, K., \& Savolainen, R. (2005). "Isms" in information science: Constructivism, collectivism and constructionism. Journal of Documentation, 61(1), 79-100. https://doi.org/10.1108/ 00220410510578023.

Tonkiss, F. (1998). Analysing discourse. In C. Ceale (Ed.), Researching society and culture (pp. 245260). Sage.

UNESCO (2003). The Prague declaration: Towards an information literate society. http://www. unesco.org/new/fileadmin/MULTIMEDIA/HQ/CI/CI/pdf/PragueDeclaration.pdf.

UNESCO (2013). Media and information literacy: Policy and strategy guidelines. https://unesdoc. unesco.org/ark:/48223/pf0000225606.

Virkus, S. (2003). Information literacy in Europe: A literature review. Information Research, 8(4), 1-35. https://doi.org/10.1007/978-3-319-03919-0_32.

Virkus, S. (2013). Information literacy in Europe: Ten years later. In S. Kurbanoglu, E. Grassian, D. Mizrachi, R. Catts, \& S. Špiranec (Eds.), European conference on information literacy (pp. 250257). Springer.

Weiner, S.A. (2011). How information literacy becomes policy: An analysis using the multiple streams framework. Library Trends, 60(2), 297-311.

Weiner, S.A. (2014). The state of information literacy policy - a global priority. Agricultural Information Worldwide, 6, 5-10.

Whitworth, A. (2011). Empowerment or instrumental progressivism? Analyzing information literacy policies. Library Trends, 60(2), 312-337.

Zurkowski, P.G. (1974). The information service environment relationships and priorities. (Report ED 100391.) National Commission on Libraries and Information Science. 